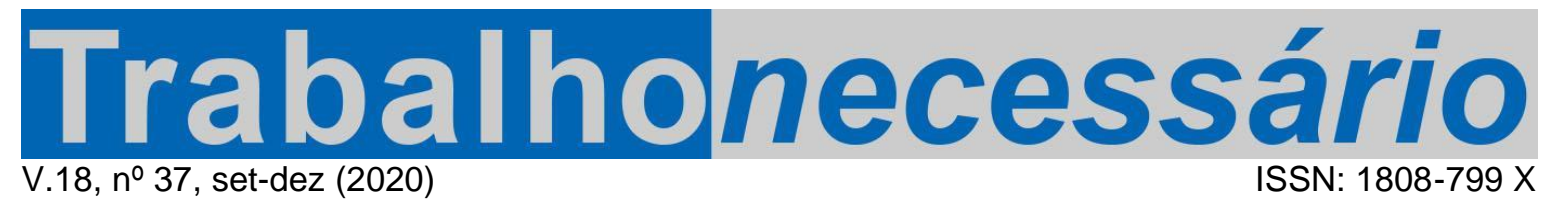

\title{
HISTÓRIA, MEMÓRIA E EDUCAÇÃO DOS REMANESCENTES QUILOMBOLAS DE BOA ESPERANÇA - PARÁ ${ }^{1}$
}

\author{
Benedita Celeste de Moraes Pinto ${ }^{2}$ \\ Vilma Aparecida de Pinho ${ }^{3}$ \\ Beleni Saléte Grando ${ }^{4}$
}

\begin{abstract}
Resumo
O estudo analisa como tem ocorrido o processo educativo na povoação remanescente de quilombolas de Boa Esperança, norte da Amazônia, tendo como base as narrativas partilhadas por seus moradores. A partir de uma abordagem de cunho qualitativo, baseada em estudos etnográficos, coleta e análise de relatos orais e histórias de vida, a pesquisa permitiu inferir que, no que tange aos desdobramentos da lei 11.645/2008, os elementos culturais da referida povoação não perpassam as práticas escolares, tão pouco nas relações que se estabelecem dentro e fora do espaço escolar, não havendo, assim, articulação entre cultura local e o processo educacional.

Palavras-chave: História; Memória; Processo Educativo; Quilombola.
\end{abstract}

HISTORIA, MEMORIA Y EDUCACIÓN EN EL AJUSTE DE QUILOMBOLAS DE BUENA ESPERANÇA - PARÁ

\section{Resumen}

El estudio analiza cómo se ha estado produciendo el proceso educativo en el resto de la aldea de Quilombolas de Boa Esperança, al norte de la Amazonía, basándose en las narrativas compartidas por sus residentes. Desde un enfoque cualitativo, basado en estudios etnográficos, recopilación y análisis de informes orales e historias de vida, la investigación nos permitió inferir que, con respecto a las consecuencias de la ley 11.645/2008, los elementos culturales de esta aldea no impregnan las prácticas escolares, ni impregnan las relaciones que se establecen dentro y fuera del espacio escolar, por lo que no tienen articulación entre la cultura local y el proceso educativo.

Palabras chave: História; Memória; Proceso educativo; Quilombolas.

\section{HISTORY, MEMORY AND EDUCATION THE REMAINING QUILOMBOLA POPULATION OF BOA ESPERANÇA - PARÁ}

\section{Abstract}

This study analyzes how the educational process has been occurring in the remaining village of Quilombolas of Boa Esperança, in the northern Amazonia, based on the narratives shared by its residents. From a qualitative approach, based on ethnographic studies, collection and analysis of oral reports and life histories, the research allowed us to infer that, with regard to the consequences of law 11.645/2008, the cultural elements of this village do not permeate school practices, nor does it permeate the relationships that are established inside and outside the school space, thus not having articulation between local culture and the educational process.

Keyword: History; Memory; Educational Process; Quilombola.

\footnotetext{
${ }^{1}$ Artigo recebido em 30/04/2020. Primeira avaliação em 27/05/2020. Segunda avaliação em 24/07/2020. Aprovado em 15/09/2020. Publicado em 25/09/2020. DOI: https://doi.org/10/22409/tn.v18i37.42443.

2 Doutora em História Social pela Pontifícia Universidade Católica de São Paulo - PUC/SP - Brasil. Docente da Universidade Federal do Pará - Brasil E-mail: celpinto18@gmail.com ORCID: 0000-00019450-5461. Lattes: http://lattes.cnpq.br/7489392738166786.

${ }^{3}$ Doutora em Educação pela Universidade Federal Fluminense - UFF/Brasil. Docente da Universidade Federal do Pará - Brasil. E-mail: vilmaaparecidadepinho@gmail.com

ORCID: 0000-0002-2544-0841. Lattes: http://lattes.cnpq.br/2018069654110698.

${ }^{4}$ Doutora em Educação pela Universidade Federal de Santa Catarina - UFSC/Brasil. Docente da Universidade Federal de Mato Grosso - Brasil. E-mail: beleni.grando@gmail.com ORCID: 0000-0002-5491-2123. Lattes: http://lattes.cnpq.br/2322323427528838
} 


\section{Introdução}

O presente estudo analisa como tem ocorrido o processo educativo na povoação quilombola de Boa Esperança, no município de Cametá/PA, norte da Amazônia, tendo como base as narrativas partilhadas por seus moradores. ${ }^{5}$ É seguindo os rastros de histórias e memórias de descendentes de antigos quilombolas que trilhamos pelas matas, rios, furos e igarapés em buscas dos ecos de resistências do processo escravista, na região do Tocantins, no Pará, tenta-se seguir pelos vestígios de caminhos difíceis, escondidos como estratégia para não serem capturados pelas tropas oficiais, que caçavam negros fugidos, cujos feitos também foram ocultados pela escrita da história oficial.

Nesta região vários povoados negros rurais têm suas origens sinalizadas pela existência desses redutos de luta por liberdade, cujos traços culturais são fortemente marcados pelo diálogo intercultural entre crenças e credos religiosos afros e ameríndios, que ao constituírem os mocambos ou quilombos da região; locais de compartilhamento de modos próprios de crer, lutar e sobreviver (PINTO, 2004, p. 50). No município de Cametá, formaram-se alguns desses focos de resistência negra, dos quais se destaca o Quilombo do Mola; no município de Mocajuba, há indícios do Quilombo do Icatu; e no município de Baião, negros libertos e fugidos se uniram na formação do Quilombo de Paxibal. Ao serem perseguidos pelas autoridades legais, se espalhavam pelas matas, criavam outros redutos negros, gerando, portanto, estratégias de resistências e vida. Ao se reagruparem em redes familiares ampliadas compuseram nossas comunidades (mini quilombos), como é o caso do antigo Quilombo de Paxibal, no município de Baião, do qual se formaram Umarizal, Bailique Centro, Bailique Beira e Igarapé Preto. Do quilombo do Mola, em Cametá, originou-se Itapocu, Porto Seguro, João Igarapé, Laguinho, Tomásia, Bom Fim, Porto Alegre e Boa Esperança. Enquanto, o Quilombo de Icatu, no município de Mocajuba, se desmembrou no Putiri (PINTO, 2010, p. 57).

\footnotetext{
${ }^{5}$ Os dados deste estudo fazem parte do banco de dados das pesquisa: Inclusão no ensinoaprendizagem: alunos de povoações remanescentes de quilombolas na produção do seu próprio material pedagógico, na região do Tocantins/PA \& Pesquisa História, Educação, Cultura e Saberes Afro Indígena na região Amazônica (PROCAD-AM), coordenadas por Benedita Celeste de Moraes Pinto.
} 
O processo escravista brasileiro não se deu de forma passiva, uma vez que negros e negras levados à condição de escravos desenvolveram estratégias de lutas e resistências, construíram histórias contra a escravidão, impondo-se de diversas formas, não fugindo de conflitos em busca por liberdade, que foram essenciais para a constituição dos redutos de negros resistentes à escravidão: os quilombos. Conforme afirma Funes (1996), não houve aceitação tácita do escravizado à sua condição social, "por um lado e, por outro, uma benevolência explícita, ou mesmo implícita, dos senhores". Deixando evidente que a luta de classe não deixou de existir, e isso ocorria de várias formas, era no cotidiano que o escravo construía a sua contraordem escravista (FUNES, 1996, p. 472). E nessa luta de classes, como afirma Edward Palmer Thompson (1987), que ocorre a partir das conjunções sociais, revelada de várias formas, a contraordem defendida por Funes (1996), que ocorria quando os negros se negavam trabalhar (especialmente pela imposição racial), quando se organizavam em rebeliões nas senzalas, arrumavam estratégias de fugas, aquilombavam-se, até mesmo se suicidando, ao serem recapturados e reescravizados. A contraordem também se dava quando se trincheiravam e lutavam pelos quilombos nos diversos combates com as tropas do Estado, que eram designadas para caçar negros fugidos e exterminar os quilombos (FUNES, 1996, p. 487).

Deste contexto histórico, trazemos as memórias insurgentes, que povoam as lembranças e as narrativas dos habitantes do povoado de Boa Esperança, que nos instigaram a refletir a respeito de como tem ocorrido o processo educativo e quais práticas pedagógicas acontecem na escola assumida nessa população. Visto que, segundo defende Brandão (2002), a questão educacional articulada com a cultura é complexa, surgindo muitas dificuldades quando se fala de educação e cultura, pois muitas vezes a educação não é pensada como algo que se completa e se relaciona com a cultura. Uma vez que, "toda teoria da educação é uma dimensão parcelar de alguns sistemas motivados de símbolos e de significados de uma dada cultura, ou do lugar social de um entrecruzamento de culturas" (BRANDÃO, 2002, p. 139).

Os processos metodológicos da pesquisa se estabeleceram a partir de diálogos com autores que se ocupam da temática em estudo, auxiliando na constituição deste trabalho. Além da pesquisa de campo, realizada a partir da observação em loco e entrevistas com estudantes, professores, habitantes da comunidade quilombola de 
Boa Esperança e de outros povoados vizinhos, cujas narrativas foram gravadas, sendo posteriormente transcritas e analisadas. Para Paul Thompson (1992), a entrevista é um dos recursos de coleta de dados na pesquisa, essencial para se compreender qualquer objeto, mas para entrevistar se faz necessário algumas habilidades específicas, como flexibilidade em encarar as diversas opiniões, o respeito por elas e a capacidade de sempre buscar compreendê-las (THOMPSON, 1992).

E, assim, a partir do diálogo estabelecido entre pesquisadoras e entrevistados(as), além do processo de coleta dos dados, compartilhamos experiências, inquietações, processos de lutas, resistências e reivindicações. Afinal, como afirma Portelli (1997), a arte essencial da história oral é ouvir, não só aquilo que acreditamos querer ouvir, mas também o que a outra pessoa considera importante dizer, e nisso nossas descobertas sempre vão superar nossas expectativas. A essencialidade do indivíduo é salientada pelo fato de a história oral dizer respeito a versão do passado, da memória. Ainda que essa seja sempre moldada de diversas formas pelo meio social, sendo que a arte de lembrar jamais deixa de ser profundamente pessoal. Pois, a memória é um processo individual, que ocorre em um meio social dinâmico, valendo-se de instrumentos socialmente criados e compartilhados. Assim, sendo o que torna a história oral diferente é que nos conta menos sobre eventos que sobre significados. As entrevistas sempre revelam eventos desconhecidos ou aspectos desconhecidos de "eventos conhecidos: elas lançam nova luz sobre as áreas inexploradas da vida diária das classes não hegemônicas" (PORTELLI, 1997, p. 22-31).

Trata-se, portanto, de uma pesquisa com abordagem qualitativa, que leva em consideração as vivências e experiências cotidianas das pessoas entrevistadas a partir da utilização da técnica de entrevista semiestruturada, mediada por conversações continuadas entre entrevistados e pesquisadoras que atendem aos objetivos de ambos (DUARTE, 2002). A pesquisa qualitativa, conforme afirmam Gerhardt e Silveira (2009), leva em consideração a compreensão de como vivem socialmente grupos sociais, enquanto pesquisadores e pesquisadoras que optam por tal abordagem buscam entender o porquê das coisas, sem a preocupação com a representatividade numérica. Ao se referirem à abordagem qualitativa da pesquisa, Ludke e André (1986) reconhecem que é no trabalho de campo que se dá de forma intensiva o contato entre o pesquisador e seu ambiente de investigação. Tendo isso 
em consideração, os dados coletados foram analisados com base em uma abordagem qualitativa, reconhecendo os valores, crenças, hábitos, atitudes e opiniões dos atores sociais que ali se encontram.

Segundo Edward Thompson (1998), no século XVIII havia clareza sobre a consciência dos usos costumeiros de uma época permeada por reivindicações de direitos dos trabalhadores, e que muitos costumes estavam em decadência, assim como a magia, a feitiçaria e superstição, ocasião em que as pessoas eram forçadas a mudar sua cultura com base em padrões e normas tidas como superiores. Ao destacar essa realidade o autor afirma que também neste contexto histórico havia resistência dos diferentes grupos populares, como trabalhadores, artesãos e camponeses, que valorizavam seus costumes tradicionais em paralelo a imersão do capitalismo já instaurado (THOMPSON, 1998). Assim, compreendemos que em cada contexto histórico os sujeitos resistem com seus modos de vidas peculiares, e por isso, embora nossa pesquisa se dê em contexto histórico diferente, reconhecemos que as populações quilombolas e indígenas no Pará também lutam por direitos e autonomia, características que os incorporam nas conjunturas sociais atuais.

Partindo das análises de Thompson (1998), buscamos refletir a respeito das populações quilombolas da região do Tocantins, enfocando fundamentalmente os habitantes da povoação de Boa Esperança e os enfrentamentos encarados nos dias de hoje, em prol de reconhecimento, valorização e legitimação de seus direitos, principalmente, no que diz respeito à educação digna, à saúde e à posse de suas terras. Nessas circunstâncias, lutam contra a tentativa de padronização, imposta pela classe economicamente dominante, que tem como referência uma única cultura, a cultura branca, dos colonizadores (THOMPSON, 1998).

Edward Thompson (1998) faz referência em seus estudos sobre esse distanciamento da sociedade formal, os atores sociais marginalizados pelo poder colonial, vistos como inferiorizados e considerados incapazes de responder aos acontecimentos do momento atual, uma vez, que eram desconsiderados pelo mundo científico e considerados atrasados pela titulada "cultura erudita", ambas representantes dos interesses das classes dominantes. Por isso, ao pesquisador não basta só descrever os costumes que resistiram e, até hoje resistem, nos lugares obscuros da margem da sociedade, como: os becos, as ruas, as matas e florestas. A tarefa é dar voz à cultura desta população, além de mostrar que os seus saberes são 
produzidos pela sociedade e que desta também se constitui. É dessa luta e resistência por legitimação de seus costumes que a sociedade se faz. A palavra "costume" foi associada ao conceito de cultura e, portanto, à segunda natureza do homem.

Isso se confirma ao percebermos que cultura é movimento, como um corpo dinâmico, flexível e em constante construção pelos diversos fatores sociais de cada sociedade (THOMPSON, 1998). Assim, o conceito de "cultura popular" é visto como sendo a manifestação do comportamento e dos costumes herdados por gerações ao mesmo tempo que a expressão das lutas sociais.

No caso das comunidades quilombolas da região do Tocantins, as pessoas mais velhas assumem o papel de preservadoras de suas histórias e memórias, na condição de guardiãs, por meio das suas experiências com um passado; são transmissoras de saberes ancestrais às futuras gerações, no intuito de garantir que costumes, hábitos e tradições permaneçam vivas e com significados próprios. Verifica-se que a cultura, que compreende os modos de vida singulares de uma população específica, como é o caso dos descendestes dos negros resistentes do processo escravista, carregam consigo, comportamentos, costumes e saberes tradicionais, que contrariam as políticas de opressão e silenciamento da cultura eurocêntrica. Dessa forma, a resistência de um povo, conforme explicita Edward Thompson (1998), não teria lugar para a classe dominante naquela sociedade e época, cuja pressão faz surgir uma "nova cultura", essa compreensão podemos levar para a cultura da globalização, nos dias atuais.

Ao voltarmos essa leitura para a realidade da pesquisa, identificamos que essa população frequenta os diversos espaços e relaciona-se com diferentes culturas, mas nesse ir e vir, ocorre o processo que conhecemos por relações interculturais. Como ocorre nas mediações interculturais estabelecidas pelas populações quilombolas e indígenas da região do Tocantins, que saem do seu lugar de origem, convivem com outras pessoas e grupos sociais e retornam trazendo consigo novas experiências, novos conhecimentos e novos sentidos, que ressignificam, sem comprometer aspectos que garantem a manutenção cultural do seu grupo de pertencimento e de identidade cultural.

É neste cenário intercultural que nos colocamos a problematizar o desafio do currículo escolar, como "norteador" de um projeto de escola, conforme defende Brandão (2002), que deveria conciliar as experiências obtidas em casa, na rua e em 
outras instituições por meio dos conteúdos escolares, enveredando por uma educação que valorize as identidades com base no diálogo entre as experiências de mundo com os saberes privilegiados na escola. Ao nos pautarmos neste autor, reconhecemos que não há um único modelo de educação ou de lugar no qual a educação possa acontecer, pois o ensino escolar não é a sua única prática e o professor o único profissional praticante. Desse modo, a educação dos habitantes das povoações quilombolas da região do Tocantins, como é o caso de Boa Esperança, ocorre por meio da oralidade, das práticas e experiências cotidianas dos seus habitantes, heranças de uma ancestralidade que se faz latente na memória dos guardiões de memórias, responsáveis pela transmissão de práticas, hábitos, costumes e saberes aos mais novos. Segundo afirma Edward Thompson (1998),

As práticas e as normas se reproduzem ao longo das gerações na atmosfera lentamente diversificada dos costumes. As tradições se perpetuam em grande parte mediante a transmissão oral, com seu repertório de anedotas e narrativas exemplares. Sempre que a tradição oral é suplementada pela alfabetização crescente, os produtos impressos de maior circulação - brochuras com baladas populares, panfletos, coletâneas de "últimas palavras" e relatos anedóticas de crimes - tendem a se sujeitar a expectativas da cultura oral, em vez de desafiá-las com novas opções (THOMPSON, 1998, p. 18).

Sendo assim, apesar da escravidão no Brasil ter sido abolida no ano de 1888, a luta do povo negro para a inclusão social ainda continua na atualidade, pois negros e negras continuam sendo desprestigiados em suas formas de viver, de compreender o mundo e crer na vida e para além dela, com isso, a eles é imposta cotidianamente pela cultura colonial atualizada, uma série de limitações e violências. As memórias e lembranças, presentes nas histórias vividas e herdadas de seus antepassados, alicerçam os registros do vivido, por meio dos quais os habitantes da povoação de Boa Esperança revisitam o passado e por intermédio da oralidade nos dando a dimensão de todo legado trazido pela ancestralidade africana, da riqueza cultural, artística, seus saberes, e a importância da sua valorização.

Nas afirmações de Davis (2000), antigamente o negro era estigmatizado pela sua condição de ter sido submetido à escravidão, não tendo direitos civis, em uma sociedade puramente tradicional, que historicamente sempre desconsiderou seus direitos, e os considerava como objeto, como propriedade (DAVIS, 2000). Nos dias atuais a população negra é excluída por inúmeras estratégias sociais naturalizadas 
pelo racismo, que se estrutura a partir de premissas, entre a qual pauta a crença da existência de raças hierarquizadas numa escala de inferioridade imposta aos não brancos. Estes, por sua vez, atribuem-se "herdeiros de uma raça europeia", cujas qualidades "mentais, morais, estéticas, religiosas" se pautam no ideal político que justifica aos demais o não acesso aos bens sociais e economicamente valorizados para o reconhecimento de sua humanidade, ao não reconhecimento de seus territórios, suas línguas, suas educações e de suas formas de viver (PINHO, 2010).

Isso é evidenciado em relação aos elementos culturais advindos do colonizador, que sempre foram privilegiados, sem deixar de mencionar o currículo pedagógico que sempre esteve voltado aos anseios de uma classe considerada branca. Por outro lado, a luta da população negra em busca da inserção social e da valorização histórica e cultural provoca mudanças, mesmo que tardiamente.

Como nos alerta Mattos (2007), em sua longa trajetória de lutas, marcadas por diferenças, preconceito e discriminação racial, a população tem conseguido levantar suas bandeiras de lutas e conquistas. Foi por meio das lutas do movimento negro reivindicando seus direitos que conseguiram várias conquistas, como por exemplo, no campo da educação, destaca-se a Lei 10.639/2003, sancionada no dia 9 de janeiro de 2003, que tornou obrigatória no currículo escolar de todos os estabelecimentos de ensino fundamental e médio, particulares e públicos o ensino sobre História e Cultura Afro-Brasileira e Africana (MATTOS, 2007, p. 191). A regulamentação desta Lei, em junho de 2004, alterou a Lei 9.394/96 de Diretrizes e Bases da Educação Nacional, representando um marco muito importante para a população negra brasileira, pois a partir de então as pessoas vão se reeducando e compreendendo as relações étnicosraciais, oportunizando aos educandos o conhecimento da história e cultura, que compõem a história e cultura brasileira e que, por muito tempo foi silenciada, revendo assim a possibilidade de todos os estudantes, independente da sua raça ou etnia, valorizarem o povo negro oportunizando a esse o orgulho de sua origem e a reconstrução das identidades afrodescendentes sem sentimentos de inferioridades (MAGALHÃES, 2010).

Em 10 de março de 2008 foi sancionada a Lei 11.645, estabelecendo Diretrizes e Bases da Educação Nacional para ampliar essa retomada da história do Brasil e valorizar as culturas marginalizadas que identificam a sociedade, tornando obrigatório incluir no currículo oficial da rede de ensino a temática História e Cultura Afro- 
Brasileira e Indígena. Mesmo com as legislações e após um processo de lutas e disputas e de conquista legal, não foram efetivados conteúdos, que revisem e apresentem as histórias silenciadas do povo negro e dos povos indígenas nas práticas escolares, especialmente, por falta de políticas públicas mais efetivas para o rompimento das amarras coloniais.

Reconhece-se assim, que são relevantes as leis, mas com elas são fundamentais os investimentos nos processos formativos e nas políticas de enfrentamento das raízes coloniais escravocratas e racistas, para que o sistema de ensino brasileiro reconheça as realidades passadas e presentes dos africanos e afrobrasileiros e dos povos indígenas. Trata-se assim, de na escola, abrir-se espaços de diálogos interculturais que prezem pela valorização da diversidade étnica e cultural como qualidade na educação brasileira, fortalecendo processos de auto reconhecimento das identidades dos estudantes, professores e comunidades escolares de suas origens ancestrais africanas e ameríndias.

Ensinar a história e cultura afro-brasileira, história da África, dos africanos e das populações indígenas nas escolas é uma formas de valorização étnicas e culturais, tanto das comunidades tradicionais, como a que pesquisamos no Pará, as quilombolas, para quebrar as barreiras que negros(as) e indígenas encontram para acessar seus espaços de cidadania na sociedade brasileira, e para contribuir com o desvelamento do preconceito e da discriminação racial. Espera-se que isso possa contribuir também para as lutas contra as desigualdades socioeconômicas e pelo exercício dos direitos e oportunidades iguais conforme prevê a Carta Magna que reconhece pela primeira vez, em 1988, a igualdade entre de todos os cidadãos. Dessa forma, começar pela escola é essencial, por ser esse o espaço-tempo em que todos se encontram desde a mais tenra idade, independente das perspectivas raciais, das crenças, dos saberes e das práticas, dos costumes; enfim, é ela um espaço em que se convive com a diversidade e a diferença, mas também nela muitas vezes encontramos diversos tipos de preconceito e práticas racistas (SOUZA, 2009, p. 92).

\section{A povoação remanescente de quilombolas de Boa Esperança na fala de seus moradores}

A povoação remanescente de quilombolas de Boa Esperança está localizada no km 55, do distrito de Juaba, Município de Cametá, no estado do Pará - norte da 
Amazônia. O acesso a essa povoação se dá via transporte terrestre, através de um ônibus que faz linha de segunda à sexta-feira, chegando até a povoação de Porto Alegre. Daí, a viagem prossegue até o povoado de Boa Esperança a pé ou de bicicleta. A distância entre as duas povoações é de aproximadamente $7 \mathrm{~km}$. A povoação de Boa Esperança ocupa uma área de terra fértil nas proximidades do campo de natureza conhecido como Anuerá. É formada por aproximadamente 105 pessoas, agrupadas em 24 famílias: sendo 25 homens, 23 mulheres; e 57 crianças, 26 meninos e 21 meninas.

A economia desse povoado gira em torno da produção e venda de farinha e demais derivados da mandioca como, tucupi, farinha de tapioca. A farinha e outros gêneros oriundos da mandioca são processados na casa de forno, que em sua maioria fica situada nos terreiros ou quintais das casas, cuja produção é comercializada, aos domingos na feira da vila de Juaba, e nos demais dias da semana na feira livre da Cidade de Cametá.

No cotidiano dos habitantes dessa povoação emergem lembranças herdadas da escravidão, principalmente, as que demarcam as bravuras e resistências dos seus ancestrais negros, que se rebelavam contra o processo escravista, através de fugas e formação dos antigos núcleos de resistências, que foram os quilombos ou mocambos. Os mais velhos habitantes desses povoados "ao revisitarem suas lembranças fazem alusão não só as bravuras dos seus avós 'resistentes' ou fugidos da escravidão, mas das dificuldades em se viver a ermo" (PINTO, 2006, p. 276). Nessa perspectiva, a memória revela-se de fundamental importância para a compreensão do processo histórico-social vivido pelos descendentes dos "resistentes da escravidez". É através dessa memória insurgente que aparecem as narrativas a respeito das histórias de constituição dos antigos quilombos e de negros(as) fugidos(as), que não se submeteram ao processo escravista na região.

São nos registros de uma memória herdada, que os moradores das povoações remanescentes de quilombolas viajam no tempo, revisitam seu passado em busca de lembranças que estão embebidas de histórias contadas pelos moradores mais velhos nos dando a dimensão de todo legado trazido nos navios negreiros pela ancestralidade africana, a riqueza cultural, artística e religiosa, assinalando a importância de negros, afrodescendentes e seus descendentes na construção da identidade brasileira. Cujas origens, como assevera Funes (1996), não são expressas 
apenas na cor da pele da sua gente, mas, sobretudo na memória, nas lembranças, que nos remetem sempre a um outro passado, que é dos antigos mocambos. Tratase, portanto, de uma história que está viva na memória dos remanescentes de quilombolas, que são netos e bisnetos, de negros quilombolas, que por muito tempo "ocuparam as matas, fazendo delas seu espaço de liberdade" (FUNES, 1996, p. 476467).

Os quilombos contemporâneos são conhecidos como comunidades remanescentes de quilombolas, que por questões políticas, relacionadas à lutas reivindicatórias dos seus habitantes pela posse e titulação de suas terras, direito assegurado no art. 68 do Ato das Disposições Constitucionais Transitórias da Constituição Federal do Brasil, são reconhecidos como espaços de terras de descendentes de negros e negras que foram submetidos(a) à condição de escravizados(as) no período colonial. As terras onde vivem seus descendestes, vieram de doações, ocupações ou foram compradas secularmente a partir de muito esforço empreendido pelo grupo, cujos habitantes, na sua maioria, vivem da agricultura de subsistência, transmitindo para os mais jovens, a partir de vivencias e experiencias cotidianas, hábitos, costumes, práticas culturais e saberes herdados dos seus ancestrais.

É no revisitar da memória dos moradores mais velhos da povoação de Boa Esperança, como, de dona Maria Gonçalves Ribeiro, 68 anos, que a história dessa povoação vai sendo reconstituída:

A comunidade de Boa Esperança foi fundada pelos irmãos Custódio Ribeiro e Juventino Ribeiro no ano de 1862. Eles moravam em Nova Alegria que é próxima da comunidade de Laguinho outra comunidade quilombola e vieram pra cá. A povoação recebeu esse nome porque suas terras eram boas de plantar. A primeira casa era de dona Maria do Rosário Ribeiro, mãe de Custódio e Juventino Ribeiro, e ficava lá na beira do campo, o barracão era de palha de muçu. Já queimou. As parteiras da povoação eram Velha Mansa e Antônia, já falecidas. Agora elas (mulheres grávidas) vão pra cidade ter filhos, porque dona Maria do Lago não se compromete mais em fazer partos (MARIA GONÇALVES, moradora da povoação de Boa Esperança).

As narrativas capturadas com base nas lembranças de dona Maria Gonçalves surgem mediante o exercício de revisitar a sua memória, as quais reconstituem as origens de formação da povoação de Boa Esperança, que teria surgido a partir da ramificação de um outro reduto negro, o povoado de Nova Alegria, cujo nome teria 
vindo da abundância de frutos e da qualidade de terras férteis, boas para a plantação. Assim como, suas lembranças também destacam a importância dos saberes das práticas de curas e arte de ajudar outras mulheres na hora do parto, que as parteiras detinham nesta povoação. E que nos dias de hoje, devido à idade avançada e com sérios problemas de visão, a única parteira da povoação, já não se responsabiliza em fazer os partos das mulheres, mas "puxa a barriga delas, ou então, faz remédio de planta pra aliviar" dores e males do corpo e do espirito. Devido não haver Posto de Saúde e nenhum profissional qualificado da área da saúde, essa parteira recomenda que as mulheres grávidas busquem apoio nos hospitais da cidade de Cametá para dar à luz aos seus filhos.

As narrativas dos habitantes desta povoação nos dão pistas a respeito dos seus saberes e aprendizados, entre os quais se incluem os referentes ao uso e técnicas de manipulação de plantas medicinais, quando buscam auxílios na sabedoria desenvolvida pelos seus ancestrais, mediante a utilização de remédios caseiros feitos à base de plantas, ervas, banhas, folhas, sementes, raízes e cascarias com propriedades terapêuticas para curar suas doenças. Driblando as dificuldades de acesso a saúde, suas práticas e saberes de curas vão sobrevivendo, proporcionando visibilidade, resistência e transmissão de uma geração para outra (PINTO, 2010).

Boa Esperança possui o formato de um semicírculo: havendo no centro o barracão, onde seus habitantes realizam reuniões e as festividades dos santos que são venerados nesta povoação. Esse barracão comunitário abriga todas as celebrações religiosas como, missas, ladainhas e romarias, além das festas dançantes. A disposição das casas lembra os traços dos antigos quilombolas, a forma de organizar suas casas de maneira semicircular demarca a solidariedade praticada pelos moradores desses núcleos de resistência, herança dos antigos quilombolas, que ainda se faz presente no cotidiano das povoações remanescentes da região do Tocantins. A maioria das casas do povoado é coberta com telha de barro, possuindo assoalhos e paredes de madeira, e, "margeando o semicírculo encontra-se a escola, ou melhor, apenas uma sala de aula" (PINTO, 2006, p. 290).

Nesse povoado não há espaço físico de nenhuma igreja, contudo, o culto ao catolicismo popular é muito forte, a partir da veneração de santos, como São Benedito, Santo Antônio, São Sebastião e Nossa Senhora do Tempo, que ao longo dos anos se alternavam na condição de padroeiro do lugar. Segundo contam alguns moradores, 
como por exemplo, o senhor José Camilo Cantão, 72 anos, primeiro padroeiro desse lugar era São Benedito, que foi festejado durante muito tempo no mês de agosto. Enquanto, Santo Antônio era festejado na época da Companhia Positiva, nesse período os moradores mais velhos realizavam os "cunvidados de planta". Além de festejarem São Sebastião, no mês de janeiro, e no mês de julho fazem a festividade da atual padroeira, Nossa Senhora do Tempo:

O Santo Antônio da Companhia Positiva, nos dias de hoje, essa geração mais nova não festeja mais, mas continua fazendo por aí o cunvidado pra plantá as roças, porque é mais rápido, num dia planta tudo a roça dum, e já vai ajudá na plantação da do outro. Tudo naquela alegria, brincadeiras, amizade e diversão, mesmo dona (CAMILO CANTÃ̃, 72 anos, morador da povoação de Boa Esperança).

A partir da narrativa do senhor José Cantão a religiosidade através das festas de santos envolvem formas de viver, resistir, celebrar, ensinar e aprender, que atravessam o mundo do trabalho permeando um tipo de produção que em certo sentido burla a lógica capitalista consumista, que individualiza, homogeneíza, e rompe com a "natureza humana" (E. THOMPSON, 1987, p. 346).

A organização do "cunvidado" ou mutirão para plantio em companhia, além de unir os trabalhadores para diminuir o tempo gasto nas atividades de preparação das roças de mandioca, cuja produção é voltada para subsistência das famílias envolvidas, produz outras formas de valores, que agrega união, lazer, estreitamento dos laços de companheiros, ensinamentos para os mais jovens e experiências de resistências, que fortalecem as formas de viver nas comunidades remanescentes de quilombolas, como ocorre em Boa Esperança.

Embora as dinâmicas empreendidas no "cunvidado", conforme afirma Tiriba (2008), não eliminem a alienação do trabalho, a propriedade e a posse dos meios de produção permitem aos descendentes de quilombolas a possibilidade de articulação de práticas e saberes que a organização capitalista do trabalho fragmentou. E, desta forma, "os processos educativos como mediação e elemento da cultura do trabalho" vai se moldando no cotidiano desse tipo de produção associada e "no movimento maior de constituição de novas relações de convivência no âmbito da sociedade" (TIRIBA, 2008, p.74).

A religiosidade dos habitantes de Boa Esperança é permeada pela influência do catolicismo mediante ao culto aos santos, cuja história de Nossa Senhora do Tempo ganha destaque, sendo envolta em causos de muita devoção e milagres. Os 
habitantes mais velhos dessa povoação narram que a imagem dessa santa teria sido encontrada por ocasião das atividades de preparação de um roçado para plantar mandioca, parecia um pedaço de madeira preste a queimar, conforme narra dona Maria Gonçalves, "era uma santinha bem perfeitinha, toda chamuscada pelo fogo, e ali no tempo aberto, foi milagre mesmo, a gente viu que era Nossa Senhora do Tempo". Ao identificar o referido pedaço de madeira como uma santa, trabalhadores Ihe atribuíram o nome de Nossa Senhora do Tempo, e devido a encontrarem no mês de julho, período tido como verão na região, passaram a festejá-la neste mês:

\begin{abstract}
Quando eu ia trabalhar na Companhia Positiva em um dos roçados encontraram um pedaço de madeira no formato de uma santa, eles deram nome de Nossa Senhora do Tempo, eu era menino quando encontraram tinha uns dez anos. A santa tem uns 62 anos agora. Ela é muito poderosa. No tempo do verão é que a encontramos, ela já ia ser queimada. O frenteio foi quem encontrou ela. Ela foi encontrada no campo. Ela foi encarnada no mês de julho, tem novena em julho, dia 14 é o dia do mastro, dia 15 é a primeira noite e 25 é a festividade. Tem romaria pelos caminhos, dentro da povoação, e cada casa dá um donativo para o bingo, leilão tudo pra comunidade (CAMILO CANTÃO, 72 anos, morador da povoação de Boa Esperança).
\end{abstract}

Os moradores de Boa Esperança contam que, para abrigar e festejar a imagem da santa encontrada, construíram um barracão com uma capelinha coberto com palhas da palmeira buçu, que após algum tempo pegou fogo. Todos as imagens de santos de veneração dos habitantes do povoado, que estavam no altar da capelinha, foram queimadas, porém, a imagem de Nossa Senhora do Tempo mais uma vez escapou do fogo, conforme se observa na narrativa de dona Maria Gonçalves:

O barracão queimou e a santa, Nossa Senhora do Tempo não queimou, ela desapareceu do altar e os outros santos ficaram e queimaram. Ela foi encontrada no terreiro, de pé. Ela não queria ser queimada de novo, foi um milagre, pois ela é de madeira (MARIA GONÇALVES, 68 anos, moradora de Boa Esperança).

Nos dias de hoje dona Maria Gonçalves é a guardiã das imagens de santos da povoação, mas diz que reserva respeito e cuidado muito especial às imagens de São Benedito e Nossa Senhora do Tempo, por serem esculpidos em madeira, são consideradas raras e protetores especiais dos habitantes de Boa Esperança. Aliás, dona Maria Gonçalves faz questão de mostrar aos visitantes o "chamusco de fogo" ainda visível embaixo do pé da imagem de Nossa Senhora do Tempo, uma marca que 
prova os milagres dessa santa, que já apareceu e desapareceu umas três vezes para não ser queimada.

Nas povoações remanescentes de quilombolas da região Tocantina, a identidade negra é vivenciada no cotidiano de seus habitantes, através de seus costumes, saberes, crenças rezas, cantorias e danças que são repassadas de geração em geração (PINTO, 2007). A memória leva a ressignificação das experiências e práticas cotidianas, e nesse sentido, a história e a historicidade é a descoberta do próprio indivíduo que traça desde o começo a trilha do pensamento, do fazer-se e os caminhos a seguir. A história é uma força aglutinadora, na qual nós apoiamos. Dessa forma, a memória tem uma importância crucial, pois é pensamento auto reflexivo que dá origens as ações individuais. Pois, há uma dinâmica entre pensamento e ação que se relaciona com a forma pela qual cada ser humano se torna consciente de estar inserido entre um passado infinito e um futuro infinito (ARENDT, 1978).

No contexto da historicidade o indivíduo é levado a agir sobre sua vida, suas condições, e isso depreende um processo criativo que tem origens na compreensão do passado. Isso pode ser observado quando os moradores mais idosos dessas povoações ao buscarem nas lembranças traços de suas raízes, tradições e costumes reclamam da falta de interesse de se trabalhar também na escola a importância da constituição histórica e cultural da povoação, fazendo com que os mais jovens dei pouca importância às festas e brincadeiras que faziam e fazem:

Hoje os nossos jovens têm vergonha da nossa cultura, só querem saber de música que não é nossa, e essa escola daqui também não ensina nada disso, então como é que eles vão gostar, não conhecem [...]. As memórias e histórias estão se perdendo porque a juventude não quer saber de mais nada e as pessoas mais velhas morrem, levam com elas. Já não se comemora como antes [...]. O samba é feito na época da festa. Os jovens participavam do samba, era demais bonita a festa aqui. O samba que é repassado de pai para filho, quando tem algum cunvidado sempre tem samba e hoje a juventude não quer sabê de mais nada (CAMILO CANTÃO, morador da Povoação de Boa Esperança).

Essa fala do senhor Camilo Cantão, um dos moradores mais idosos de Boa Esperança, soma-se a de outros(as) habitantes desse e de outros povoados da região do Tocantins, reivindicando que as escolas de áreas quilombolas tragam para seus espaços temas que estejam presentes na realidade desses sujeitos, escutar suas 
histórias de vida, problematizando o contexto social, político e cultural por eles vivenciados, permitindo com que o processo educativo formal, também seja um instrumento de luta dessa população.

Observa-se que nessas escolas, referente à religiosidade, por exemplo, ainda há predominância da influência do cristianismo, a partir do catolicismo e das igrejas evangélicas, ocultando diferentes rituais de louvação aos seres da natureza, que ocorrem durante os plantios e colheitas das roças, por ocasião dos nascimentos ou despedidas, nas curas através de rezas e com poções feitas com ervas, plantas, raízes, banhas e semente. Isso tudo se caracteriza como herança da ancestralidade negra, que é manejada pelos mais velhos, pessoas sábias, detentoras de diversos saberes, que estão imbricados nas vivências cotidianas quilombolas. Daí, por que reivindicam uma educação quilombola que atenda às necessidades dos habitantes dessas comunidades, através de um currículo que incorpore nas atividades educacionais constituição histórica, saberes tradicionais, práticas culturais, formas de trabalhos e vivências cotidianas, respeitando questões étnico-raciais permitindo que o processo educativo formal, também seja um instrumento de luta dessa população.

\section{O processo educacional no povoado remanescente de quilombolas de Boa Esperança.}

A povoação remanescente de quilombolas de Boa Esperança possui uma pequena escola, cuja estrutura física dispõe apenas de uma sala de aula, razoavelmente ampla, isso se levar em consideração as salas de aulas de muitas povoações remanescentes de quilombolas da região do Tocantins. No entanto, observa-se poucas carteiras, uma mesa para o professor, um quadro para atividades do professor, dois banheiros (sendo um feminino e um masculino), uma pequena copa, onde há um fogão a gás de duas bocas, uma sala em que são guardados os materiais da escola como: cadernos, lápis, borracha, alguns jogos didáticos e uma caixa d'água. Em relação às escolas das povoações remanescentes de quilombolas por onde se passou no decorrer da pesquisa, como Mola, Bom Fim, Tomásia e Laguinho, a escola de Boa Esperança apresenta um melhor espaço físico.

Inicialmente a escola funcionava no barracão de festa e reuniões desse povoado, após haver um incêndio, foi transferida para a casa de um morador, cujo espaço foi posteriormente alugado pela secretaria de educação do município de 
Cametá. O funcionamento da escola na casa de um morador é um tipo de acordo corriqueiro na zona rural, estabelecido entre o poder público e um morador local para que na comunidade possa ter um espaço físico próprio da escola, embora não seja este assumido em termos de condições estruturais pelo Estado. Neste acordo é pago uma quantia irrisória de dinheiro a um determinado morador pelo aluguel da sua residência, que será o local de funcionamento da escola, uma espécie "de cala boca", ou seja, faz com esse morador se acomode, não reclame juntamente com os demais a ausência de escola para os seus filhos, devido acreditar que está lucrando, enquanto isso, o poder público vai postergando sua responsabilidade e mantendo o racismo institucionalizado ao não atender de forma igual aos estudantes e professores da comunidade.

A construção da atual escola só aconteceu após praticamente uma década de lutas reivindicatória dos habitantes de Boa Esperança, que organizados pressionaram insistentemente o poder público local. Importante observar, que o poder público transfere, em um processo alienante, suas responsabilidades e deveres legais para a população local, privatizando o seu papel na educação. Segundo afirma Freire (1996), trata-se da ideologia fatalista e imobilizante neoliberal, que com ares de pósmodernidade, anda solta no mundo, insistindo em "convencer-nos de que nada podemos contra a realidade social que, de histórica e cultural, passa a ser ou a virar "quase-natural", restando para a prática educativa adaptar o educando a esta realidade que não pode ser mudada (1996, p. 19-20).

No primeiro momento da pesquisa se observou que o quadro de funcionários da E. M. E. F. Boa Esperança era constituído de apenas 02 professores polivalentes, ou seja, trabalham em sala multissérie, realidade corriqueira nas escolas de áreas quilombolas. Além de ministrarem aulas, executam outras atividades na escola e se envolvem nos acontecimentos da povoação. Essa é uma das realidades vividas pela maioria das crianças e jovens das comunidades remanescentes de quilombolas da região do Tocantins, nas quais o ensino ainda acontece pelo sistema multisseriado. Nesse molde de ensino convivem alunos de idade e séries diferentes em uma sala de aula. E um único professor tem que se desdobrar em vários professores, tentando desenvolver as mais variadas estratégias para vencer cada dia de aula (PINTO, 2006).

Neste malabarismo circense do professor polivalente e artista do quase improvável, os mais prejudicados são os seus alunos, que apresentam muitas 
dificuldades de aprendizagens, independentemente da idade. Pois, nas turmas multisseriadas da região, existem crianças a partir de 04 anos e jovens com 15 anos de idade, todos apresentam algum tipo de dificuldade no processo de aprendizagem. Interessante destacar que as orientações curriculares desde a educação infantil até o ensino médio preveem a organização das turmas de estudantes por faixa etária, tendo sido efetivado os ciclos de aprendizagens e outras políticas, como a atual Base Nacional Curricular Comum, que organiza o sistema de ensino de forma a padronizar os sistemas municipais e estaduais com o nacional. Porém, nesta comunidade historicamente de resistência e luta por reconhecimento dos seus direitos, o Estado Brasileiro mantém o processo de subjugo com justificativas na contramão das normativas e legislações vigentes. Essa situação se agrava ainda mais devido à ausência de espaço da sala de aula ou da precária estrutura física das escolas. Sem falar da falta de transporte escolar, merenda escolar e outros.

No tocante a sala de aula da escola de Boa Esperança, verificou-se que não consegue abrigar confortavelmente todos os alunos, pois, além de frequentarem os alunos que estão regularmente matriculados, há ainda os chamados "alunos encostados", que pela ausência de documentos necessários (como certidão de nascimento) para que suas matrículas sejam efetuadas, ou por serem crianças temporárias na povoação, devido ao trabalho dos pais (PINTO, 2006), assistem às aulas de forma voluntária, sem compromisso da Secretaria de Educação do município.

Atualmente estudam 53 alunos nessa escola, sendo que no turno da manhã funciona uma turma multisseriada composta por 25 crianças do jardim I até o $2^{\circ}$ ano do ensino fundamental. E no turno da tarde são atendidos 28 alunos, em uma turma multisseriada composta por estudantes do $3^{\circ}$ ao $5^{\circ}$ ano do ensino fundamental. Observamos que no jardim III há uma criança com Necessidades Educacionais Especiais - NEE - com diagnóstico de surdez total e pouca audição. Quando indagamos ao professor Janil Moraes, responsável pela turma multissérie, na qual estuda esse aluno, acerca das metodologias utilizados para trabalhar com os mesmos, sua resposta foi emblemática:

[...] a escola não dispõe de recursos didáticos para esse ensino. [...] no interior as dificuldades são maiores, principalmente pelo fato de trabalhar com multisseriado, e também porque a gente se reuni uma vez no ano com a Secretaria de Educação para o planejamento, daí vem a supervisora saber se a escola vai bem, se a comunidade aceita o professor, se estão gostando dele, se reuni com os pais pra saber o 
que a comunidade precisa (PROFESSOR JANIL MORAES, morador de Boa Esperança).

Buscando compreender como essa escola tem acesso aos direitos legais que na educação potencializaria o auto reconhecimento étnico e cultural e a valorização das histórias e culturas afro-brasileiras como a da comunidade, trazemos a fala deste professor que se refere não só as dificuldades enfrentadas devido à ausência de materiais didáticos e paradidáticos, mas também a falta de cursos de aperfeiçoamento para qualificar a educação escolar acerca dos dispositivos da 11.645/2008. Isso reforça o abandono e a falta de políticas públicas para os quilombolas da região, pois não há investimentos para que possam ser revistos os processos históricos de imposição colonial visando o reconhecimento e valorização das diversidades e dos diversos saberes dessas populações. Nesta direção, também não é ofertado o curso de libras e não recebem nenhum tipo orientação para lidar com um aluno com NEE. Sem falar que esse professor trabalha com uma turma multisseriada, situação que dificulta ainda mais seu trabalho e a aprendizagem dos estudantes.

No entanto, como um contraponto, observou-se que a maioria dos estudantes de Boa Esperança concluem seus estudos no 6ำ ano do ensino fundamental. Aqueles que se predispõem em continuar estudando, são obrigados a se deslocar até a escola da povoação quilombola de Porto Alegre, que atende até 0 9 ano do ensino fundamental. Há casos que para continuar os estudos, os jovens, na maioria mulheres, mudam-se para a cidade de Cametá, onde moram com algum parente e trabalham como domésticas ou diaristas. Isso expressa ainda que as dificuldades em conciliar estudos e trabalho acarretam a desistência dos estudos. Assim, os fatores de ordem econômica são os principais responsáveis pelo não acesso aos direitos à formação escolar, os quase se articulam aos fatores subjetivos de ser negro em uma sociedade ainda racista, tornando o acesso à escola e ao ensino superior um desafio quase impensável aos jovens quilombolas na região. Isso porque enfrentam, além da pobreza material, os processos de exclusão, preconceito e discriminação racial institucionalizada e invisibilizada nas relações sociais naturalizadas no cotidiano das cidades.

É importante mencionar, que não basta criar leis, obrigando a conhecer e estudar as realidades passadas e presentes das populações africanos e indígenas, mas, antes disso, é imprescindível construir cenário para sua efetivação, com mudanças tanto administrativas, quanto pedagógicas para que realmente sejam 
colocadas em prática, visto ser necessário de se educar estudantes com consciência política e histórica, que valorize e respeito às diversidades reconhecendo as suas individualidades e ao mesmo tempo o seu direito à igualdade.

Nos casos das escolas de áreas quilombolas da região em estudo, verificou-se que a cultura afro-brasileira e africana é trabalhada de forma superficial, apenas em situações específicas, como por exemplo, no ensino de história, quando as discussões em salas de aulas é a escravidão negra no Brasil ou em datas comemorativas, como: Semana da Consciência Negra, Abolição da Escravatura e dia do folclore. Os textos, as gravuras e os desenhos trabalhados nas aulas não fazem referência alguma à cultura afro-brasileira, tampouco refletem o contexto sociocultural no qual as crianças estão inseridas. A partir disso, observa-se que "o currículo adotado nas escolas dessas povoações ainda segue os mesmos padrões estabelecidos pelo sistema formal de ensino. Não considera o modo de vida e as experiências cotidianas dos alunos" (PINTO, 2006, p. 283).

Contudo, verifica-se que há preocupação de grande parte dos moradores das povoações quilombolas, assim como, de professores, que reclamam da falta de atenção dispensada para o conhecimento das histórias de constituição dessas comunidades, suas práticas culturais, hábitos e costumes herdados dos seus ancestrais. Visto que, os conhecimentos resultantes não levam em consideração os processos ocorridos na vida dos alunos, e assim são materializados nos programas educacionais e livros didáticos, quando o conhecimento escolar se torna "objeto", "coisas", a ser transmitida (DAYRELL, 2001). As práticas desvinculadas da realidade, tendem a seguir modelos de currículos direcionados para escolas de áreas urbanas, descontextualizadas das realidades de estudantes quilombolas, que, na sua grande maioria, vivem em áreas rurais. O processo de educação continuada dos professores que vão atuar em sala de aula, no que diz respeito às relações étnicas e indígenas, deve ser ininterrupto, ou seja, está sempre procurando aprender, frequentando cursos, participando de palestras, para assim melhorar seu desempenho em sala de aula.

Durante as atividades de pesquisa de campo observamos que alguns professores de escolas quilombolas vêm buscando a formação continuada para trabalhar com o ensino da história e da cultura negra e indígena, iniciativa fundamental para que seja revisto, principalmente na educação, devido ao processo de 
invisibilidade e exclusão enfrentados pelos habitantes destas comunidades. A maioria dos professores quilombolas entrevistados, como é caso dos professores de Boa Esperança, afirmam já ter feito uma formação continuada na área, ou dizem já ter reclamado junto a Secretaria de Educação do Município de Cametá, algum curso de formação nesse sentido. Assim como, dizem que participam de cursos e palestras, com esse propósito, promovidos por professores pesquisadores do Campus Universitário do Tocantins/UFPA- Cametá, os quais constantemente oferecem cursos sobre relações étnicas, abordando o ensino da história, cultura afro-brasileira, africana e indígenas:

Olhe, pra the falar a verdade na secretaria de educação do município não se aproveita quase nada, é só enrolação. Eu gosto de participar mais desses eventos que acontecem aí na universidade, a UFPA, aqui em Cametá, tem palestras, oficinas, cursos, que trata de assuntos da nossa realidade, da nossa cultura, nossas festas, a importância da terra quilombola, das nossas escolas. E, assim, tudo de graças, a gente não paga nada pra participar, mas tudo ali é ótimo, esclarece muita coisa pra gente trabalhar com nossos alunos, e eles gostam muito, ficam olhando diferente os velhos, com admiração, orgulho mesmo (PROFESSOR RAIMUNDO GONÇALVES, morador da povoação de Boa Esperança).

Partindo da fala desse professor observa-se que a formação parte do próprio sujeito que por sua vez tem uma posição crítica sobre o que se "transfere" nas formações oficiais e o que aprende com seus próprios meios e valorização de sua comunidade. Percebe-se que os próprios professores buscam se inteirar sobre o ensino da história e da cultura afro-brasileira e africana, para inserir nas suas práticas na escola, disseminar entre os estudantes. Neste sentido, estão pensando em práticas pedagógicas que contemplem a diversidade cultural da qual fazem parte, que possibilitem aos estudantes compreenderem-se enquanto sujeitos ativos, "com capacidade de transformar o seu cotidiano" (LIMA e VIEIRA, 2006, p.31). Percebe-se ainda que há casos de professores de Boa Esperança, que possuem só o ensino médio, mas que tentam fazer o curso superior a exemplo dos colegas que exercem o magistério nas povoações de Bom Fim e Mola, pagando com seus próprios salários. No mesmo sentido de busca de qualificação, verificam-se casos de professores quilombolas que estão cursando nível superior pelo Programa Nacional de Formação de Professores da Educação Básica - PARFOR/CAPES ou então na Universidade Federal do Pará (UFPA), a partir da aprovação no Processo Seletivo Especial para 
estudantes indígenas e quilombolas dessa instituição, como ocorre com professores que moram na povoação quilombola de Porto Alegre, que ministram aulas em escolas dos municípios de Oeiras do Pará e Baião.

Diante da pesquisa com essas realidades históricas e seus processos para o acesso à escola em áreas quilombolas, o procedimento educativos das mesmas precisa ser repensando frente às multiplicidades identitárias que se inscrevem no contexto escolar, o que, ao nosso ver, requer a necessidade de se considerar e respeitar as experiências dos estudantes a partir do reconhecimento e valorização dos seus comportamentos, rituais, tradições, heranças e todo contexto histórico, pois estas contribuem para a construção da identidade étnico-racial no espaço escolar, assim como, fortalece a luta dos professores por formação específica, que possam atender a compreensão dos processos interculturais que perpassam a prática pedagógica em turmas, cujas identidades são diversificadas (em idade, gênero, grupo familiar, e outros), ou seja, tanto para atuarem nessas comunidades, bem como, na educação de modo geral.

\section{Considerações Finais}

Ao tecer algumas considerações acerca dos desdobramentos educacionais referentes à consolidação da 11.645/2008 na povoação remanescente de quilombolas de Boa Esperança, verifica-se que os moradores dessa comunidade continuam a valorizar as formas tradicionais de viver coletivo, ao ressignificar a cultura de seus antepassados, intercalando momentos de lazer, com suas festas, danças e ladainhas, com o trabalho nas roças de mandioca. Na pesquisa em Boa esperança, são evidenciadas heranças ancestrais da comunidade expressos nas formas de organização espacial, de festejar os santos venerados, de solidarizarem-se entre moradores, de fazer a economia girar em torno da produção e venda da farinha de mandioca e de seus derivados e de praticar o samba de cacete; elementos essenciais da cultura quilombola da região.

No entanto, quanto ao processo educacional, a pesquisa traz ao debate o grande distanciamento do acesso aos direitos já firmado pelas legislações em vigor. Ou seja, embora alguns estejam assegurados nas legislações esses não são efetivados, uma vez que tantos os moradores, quantos os professores desse povoado 
reclamam da falta de escolas com espaços dignos e inclusivos, assim como da formação de professores que possam ser garantias de organização de um currículo escolar que atenda a realidade local sem desconsiderar os direitos constitucionais de cidadãos cujo acesso aos diferentes sistemas de ensino deva ser assegurado.

Dessa forma, é imprescindível pensar a escola como construtora de identidades positivadas no sentido de igualdade de direito e do reconhecimento a diferença sem desqualificá-la. Esse espaço da educação escolar como local de efetivo exercício de aprendizagem da cultura negra, oportunizará as crianças, jovens e adultos viverem a diferença na igualdade a caminho para uma sociedade antirracista.

Por fim, em consonância com os estudos de Gatinho (2008), reconhece-se que apesar de haver algumas mudanças no processo educacional a partir da promulgação da lei 11.645/2008, a maioria dos professores quilombolas, também ainda deixam de inserir no espaço escolar muitos elementos da cultura negra, que poderia fazer parte de sua prática pedagógica.

\section{Referências}

ARENDT, H. A vida do espírito: Querer. Vol. II. Lisboa: Instituto Piaget, 1978.

BRANDÃO, C. R. O que é educação. São Paulo: Brasiliense, 2002.

DAVIS, D. J. Afro-brasileiros hoje. São Paulo: Summus, 2000.

DAYRELL, J. A escola como espaço sócio-cultural. In: Múltiplos olhares sobre educação e cultura. Belo Horizonte: Editora UFMG, 2001.

DUARTE, R. Pesquisa Qualitativa: Reflexões Sobre o Trabalho de Campo. In: Cadernos de Pesquisa, n. 115, p. 139-154, março/ 2002. Disponível em https://www.scielo.br/pdf/cp/n115/a05n115.pdf. Acesso em 20/03/2020.

FREIRE P. Pedagogia da autonomia: saberes necessários à prática educativa. 27. ed. São Paulo: Paz e Terra; 1996.

FUNES, E. A. "Nasci nas matas, nunca tive senhor". Histórias e memórias dos mocambos do baixo amazonas. In: Liberdade por um fio: histórias dos quilombos no Brasil. São Paulo: Companhia das Letras, 1996, p. 467- 493.

GATINHO, A. A. O movimento negro e o processo de elaboração das diretrizes curriculares nacionais para a educação das relações étnico - raciais. Dissertação (Mestre em Educação). Universidade Federal do Pará, Belém, 2008. 
GERHARDT, T.E; SILVEIRA, D. T. (orgs). Métodos de Pesquisa. Porto Alegre: Editora da UFRGS, 2009.

LIMA, P. A.; VIEIRA, T. Educação inclusiva e igualdade social. São Paulo: Avercamp, 2006.

LÜDKE, M. e ANDRÉ, M. E. D. A. Pesquisa em Educação: abordagens qualitativas. São Paulo: EPU, 1986.

MAGALHÃES, L. de L. A Lei 10.639/03 na educação do campo: garantindo o direito às populações do campo. In: ROCHA, M. I. A., HAGE, S. M. (orgs). Escola de direito: reinventando a escola multisseriada. Belo Horizonte: Autêntica Editora, 2010.

MATTOS, R. A. de. História e cultura afro-brasileira. São Paulo: Contexto, 2007.

PINHO, V. A. Jovens negros em processo de "ressocialização": Trajetórias de vida e escolarização. Programa de Pós-Graduação em Educação - UFF. Tese de Doutorado. 2010.

PINTO, B. C. de M. Filhas das matas: práticas e saberes de mulheres quilombolas na Amazônia Tocantina. Belém, Açaí, 2010.

Memória, oralidade, danças, cantorias e rituais em um povoado Amazônico. Cametá: B. Celeste de M. Pinto Editora, 2007.

Nas veredas da sobrevivência: memória, gênero e símbolo de poder feminino em povoados amazônicos. Belém: Paka-Tatu, 2004.

. Os Remanescentes de Quilombolas na Região do Tocantins (PA): História, Cultura, Educação e Lutas por melhores condições de vida. In: BRAGA, M. L. de S.; SOUZA, E. P. de; PINTO, A. F. de M. (org.). Dimensões da Inclusão no Ensino médio: mercado de trabalho, religiosidade e educação quilombola. Brasília: Ministério da Educação, Secretaria de Educação Continuada, Alfabetização e Diversidade, 2006: 271-302.

PORTELLI, A. O que faz a História Oral diferente. Tradução. Maria Therezinha Janine Ribeiro. In: Revista Projeto História. PUC/ São Paulo, fevereiro de 1997, p. 25-39.

SOUZA, M. de M. A descoberta da África. In. FIGUEIREDO, Luciano (Org.). Raízes Africanas. Rio de Janeiro, RJ: Editor Sabin, 2009.

THOMPSON, E. P. A formação da classe operária inglesa: a árvore da liberdade. 4. ed. São Paulo: Paz e Terra, 1987. V.1.

Costumes em comum. São Paulo: Companhia das Letras, 1998.

THOMPSON, P. A voz do passado: história oral. Rio de Janeiro: Paz e terra, 1992.

TIRIBA, L. Cultura do trabalho, autogestão e formação de trabalhadores associados na produção: questões de pesquisa. Perspectiva, Florianópolis, v. 26, n. 1, p. 69-94, jan./jun. $2008 . \quad$ Disponível em: https://periodicos.ufsc.br/index.php/perspectiva/article/view/2175-795x.2008 v26n1p69/9566. Acesso em 20/03/2020. 